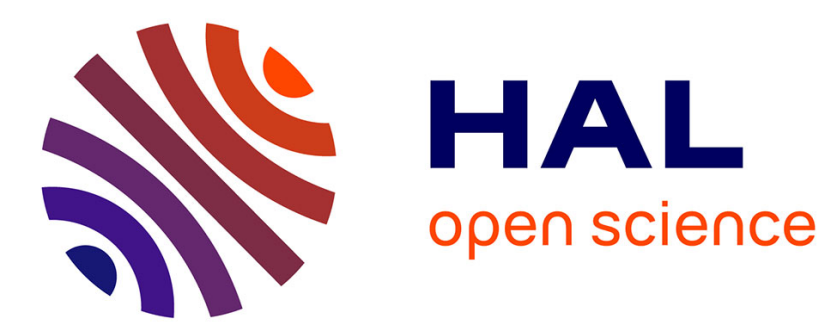

\title{
Proximity dynamics and the geography of innovation: diminishing returns or renewal?
}

\author{
Marie Ferru, Alain Rallet
}

\section{To cite this version:}

Marie Ferru, Alain Rallet. Proximity dynamics and the geography of innovation: diminishing returns or renewal?. Richard Shearmur, Christophe Carrincazeaux and David Doloreux (eds), Handbook on the Geographies of Innovation, Edward Elgar Publishing, pp.100 - 122, 2016, 10.4337/9781784710774.00013. hal-02025328

\section{HAL Id: hal-02025328 \\ https://hal.science/hal-02025328}

Submitted on 19 Feb 2019

HAL is a multi-disciplinary open access archive for the deposit and dissemination of scientific research documents, whether they are published or not. The documents may come from teaching and research institutions in France or abroad, or from public or private research centers.
L'archive ouverte pluridisciplinaire HAL, est destinée au dépôt et à la diffusion de documents scientifiques de niveau recherche, publiés ou non, émanant des établissements d'enseignement et de recherche français ou étrangers, des laboratoires publics ou privés. 


\title{
Proximity dynamics and the geography of innovation: diminishing returns or renewal?
}

\author{
Marie Ferru and Alain Rallet
}

This is a draft chapter. The final version is available in Handbook on the Geographies of Innovation, edited by Richard Shearmur, Christophe Carrincazeaux and David Doloreux, published in 2016, Edvard Elgar Publishing Ltd

https://doi.org/10.4337/9781784710774.00013

The material cannot be used for any other purpose withut further permission of the publisher, and is for private use only

\section{INTRODUCTION}

Discussions on the role of proximity in the organization of economic activities first started 25 years ago. We know what happened next (Benko, 1998). In the early 1990s, a small research group composed of French economists, some from the field of industrial economics and others from regional economics, took up the task of analyzing relations between the geography of activities and their industrial dynamics based on the notion of proximity. This is a concept with many meanings, but with its roots firmly planted not only in geography but also in economics and socioeconomics. Indeed, the interesting feature of this concept was that it was impossible to reduce proximity to its geographic dimension as it had so many other forms.

Thus the "proximity" concept was able to condense the group's "epistemological program", which consisted in analyzing the relationship between territory and industry, not as a relationship of expression (space as a geographic projection of industrial organization or, conversely, as an incarnation of geographic determinism), but as a dialectical relationship where the two terms are co-determined simultaneously. Proximity was seen as an analyzer of this relationship, as through its many forms it included the need to connect space and economy together, something which had always proved difficult. The originality of the group's work was therefore not the use of the word itself, but using it with this divided meaning and making this division the departure point for their studies, as until then the notion had been understood only in terms of its geographic dimension.

Two questions were then posed, corresponding to the two possible approaches to the space/industry relationship using the multi-meaning proximity concept. First, how does geographic proximity explain the territorialization of economic activities, given that other forms of proximity can account for this geography? And second, to what extent can territory, understood as a a node of proximity relationships, generate specific industrial dynamics? Although these two questions were not limited to the problem of innovation, studies soon focused on this problem, owing, on the one hand, to public policy issues (what is the rationality behind cluster policies and what is their scope?), and on the other hand, to the fact that innovation activities, more than any others, were presumed to require a strong geographic proximity.

The group quickly extended its scope to cover more disciplines, as the interconnection of proximities was also of interest to sociologists, geographers and town planners. In addition, questions other than innovation were covered (the city, conflicts, etc.). National and then international conferences were organized every 2 years and the impetus was maintained. 
Since the inaugural issue of the Revue d'Economie Régionale et Urbaine in 1993, special issues of French journals have also been produced (Economie Rurale (2004, no.280), Revue d'Economie Régionale et Urbaine (2008, no.3), Nature, Sciences, Sociétés (2009, vol. 17, no.4) and also international journals (International Journal of Sustainable Development (2004, vol. 7); Regional Studies vol. 42, issue 6, 2008, Regional Studies vol. 49, Issue 6, 2015, etc.). As a result of numerous seminars and workshops, many papers have been published. ${ }^{1}$ Journals have accepted an ever-growing number of contributions (see above) and many doctoral theses have been written on these subjects since the mid-1990s, clear proof of the interest shown by young researchers in an approach to socioeconomic geography based on notions of proximity. Lastly, institutional initiatives have been introduced bringing research laboratories together to develop applied studies on the geography of innovation, to deal with measurement issues and produce localized data (see the Eurolio network). ${ }^{2}$

Overall, there was a fairly steady growth in research on this subject until the beginning of the 2000s, then everything exploded: the concept of proximity was popularized and internationalized, bringing it into mainstream economics and leading to a proliferation across the board of studies on proximity. The idea spread that the concept of proximity could be applied to all subjects, that its different forms could be found and assessed in a range of economic or social fields.

However, the question of the geography of activities and of innovation in particular still remained one of the main issues in the work raised by the French School of Proximity. Many authors, such as Boschma (2005), Torre (2006), Ponds et al. (2007), Lorentzen (2007), Carrincazeaux et al. (2008), Massard and Mehier (2009) and Ferru (2010), have attempted to explain the link between proximity and innovation by considering innovation activity as the resultant of various types of proximity. Many applied studies have been and continue to be produced.

Twenty-five years later, how do we situate all these studies? Our aim here is not to propose a new survey of studies on proximity and innovation. There are already some excellent ones, to which we make reference (Bouba-Olga et al., 2008; Carrincazeaux et al., 2008). Our aim is rather to examine the trajectory of these studies, the stage they have reached in their life cycle: rise, maturity or decline? Is there saturation or renewal? Burnout or resilience?

This paper therefore provides a critical review of proximist literature on the geography of innovation from the point of view of its future prospects. We shall answer the following questions: 1) how have studies evolved? 2) in what direction are they developing today? 3 ) what are the best avenues for renewal, that is to say how to escape diminishing returns? In fact, despite the significant contribution made by the work of the "proximists" in analyzing the geography of innovation, we are currently witnessing an upsurge in empirical studies and an accumulation of results where value added is not always evident. This is a widespread phenomenon, applicable to any research group: creativity tends to fade over time. This is why it is useful to look at the stage in its life cycle that a research trend such as this one on proximity and innovation has reached.

We will first put forward a periodization of studies on proximity based on the publications it has produced (I.). Next, we will consider the specific content of the two periods that we define (II. and III.). Lastly, we suggest some avenues for renewal which may lead to a "rebound cycle" (IV.).

\section{STAGES IN THE DEVELOPMENT OF STUDIES ON PROXIMITY AND INNOVATION}


We identified publications combining the key words "proximity and innovation" since the beginning of the 1990s. Articles were selected by applying three different filters:

- direct contributions (words present in the title)

- total audience of the trend (words present in the body of the text)

- intermediate level (words present in the abstract)

There were few direct contributions and their numbers remained relatively stable over the period studied. For the other categories there was a marked dynamic with two major breaks defining three main periods (shown in the figure 1.1).

Figure 1.1: Weight and evolution of different categories of authors dealing with "proximity and innovation"

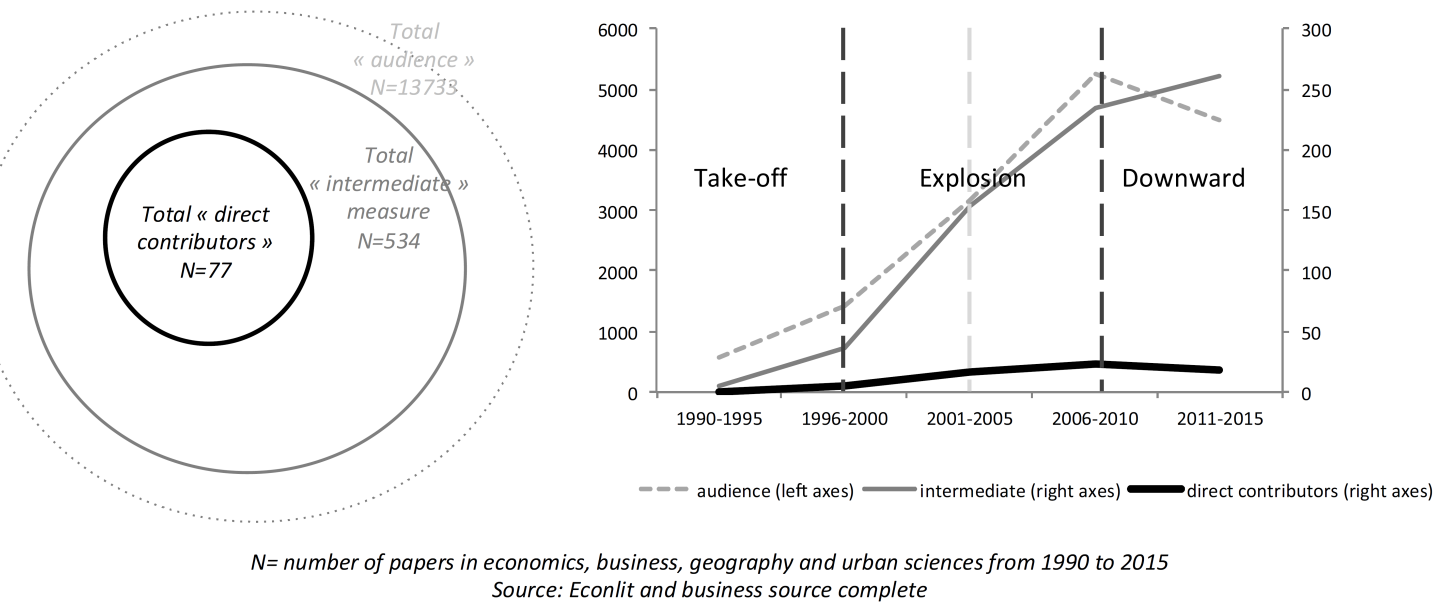

The first period is the founding period (1990-2005) marked by the predominance of works by the French researchers who were involved in starting the trend. It begins with the special issue of the Revue d'Economie Régionale et Urbaine (1993), bringing together contributions from the core group of founder members. In this first period, we also find theoretical discussions which aimed to set out an analytical framework (see Pecqueur and Zimmermann, 2004) as well as a first set of empirical studies (see the review by Dupuy and Burmeister, 2003), and the objective of linking the subject to the debate on public territorial innovation policies. Bi-annual conferences were held, the first organized in Toulouse in 1995, and these provide a framework for the dissemination of the proximity approach. It was in this way that the audience for this trend began to grow. These conferences fairly quickly became the ideal place for discussions between researchers from different disciplines and of different nationalities.

This first period seems to be mainly formed of contributions from a group of French researchers working around the founder members of the School of Proximity. Confrontations between theoretical development and field research are in evidence. Some authors focused their attention on the very definition of proximity and suggested refining the analytical categories (Gilly and Torre, 2000; Pecqueur and Zimmermann, 2004; see below) while, at the same time, case studies were being carried out (Rallet and Torre, 2001; Carrincazeaux et al., 1998; Belis-Bergouignan, 1997; etc.). Thus the work of the founders developed and indeed occupied a recognized place in the academic landscape of regional 
science at the beginning of the 2000s, but their influence remained for the most part national.

The second period was marked by much more in-depth analysis, many more empirical studies and the internationalization of research. The publication in 2005 of a special issue of the journal Regional Studies marked a turning point as it set out some analytical propositions which opened the way to broader empirical studies to test these propositions and widen their audience in academic circles. The article by Rallet and Torre (2005) defines the notion of proximity based on the interrelationships between spatial and non-spatial proximities, taking into account Information and Communication Technologies as a support for coordination and economic actors capacity for ubiquity, showing the importance of temporary geographic proximity and making the distinction between proximity and localization. A second article, by Boschma (2005), defines and operationalizes the analysis by distinguishing five categories of proximity. These analytical clarifications paved the way for empirical studies on databases in France (Autant-Bernard et al., 2007) and elsewhere (especially the Netherlands, see below).

After 2010, we observe a slowdown in the number of publications, leaving open the question of whether we are now entering a $3^{\text {rd }}$ period. This is marked more by legitimate methodological concerns than by intellectual creativity, though there are frequent reminders that wide-ranging theoretical debates are needed. ${ }^{34}$ There are most notably two important points, outlined in two special issues on proximity: ${ }^{5}$ first, the desire to improve the tools used to measure proximity, and second, the desire to internationalize the approach. The predominance of empirical studies and their internationalization are very much linked with the growing interest among public innovation policies for "clusters". Are these policies well-founded? Is it right to use public funding to support cluster-based policies? Are they "effective"? To determine this, we need to understand how the innovation actors (firms, research centers, etc.) organize innovation processes in spatial terms in the different sectors. Many empirical results have been accumulated, and although the debate continues, authors converged to the limited role of geographic proximity in coordinating innovation activities, which was basically what the founders sought to show.

Thus we can say that the program of the School of Proximity has largely been achieved. But this raises the question of revitalizing our subject matter as we cannot be satisfied with endlessly repeating the same studies, especially as the results tend to converge. This is why we are calling for a renewal in this subject area. Some contributors have already achieved this by broadening the proximity approach to objects outside the innovation field (explaining conflicts, coordinating non-innovative activities, etc.). Renewal can also be considered as the incorporation of new questions, which may or may not be in the field of innovation.

\section{ISSUES AND FOUNDING PRINCIPLES OF PROXIMITY STUDIES}

For a better understanding of the trajectory of studies on proximity, let us go back to the beginning. With the growth of regional science studies on industrial districts and innovative environments, "proximity group" authors opposed what they considered to be a "localized presupposition" (Gilly and Torre, 2000, p26). An analytical framework was produced, showing that there was a multiplicity of forms of proximity, which supported their claims. Indeed, it enabled authors to deduce the territory from the analysis, as a set of interrelated proximities, instead of assuming it a priori. They could then renew public policy recommendations. 


\section{THE STARTING POINT...}

A group of French researchers, mainly economists, sociologists and geographers, found that research on industrial districts and innovative milieus was two much territory-biased at the beginning of the 1990s. They joined together to strengthen the scientific basis of their work, at a time when studies by the GREMI appeared to predominate in regional economics. ${ }^{6}$ The group's main aim was to use an analysis based on spatial and non-spatial proximities, which would lead to alternative public policy recommendations by highlighting the localized presuppositions of the innovative milieu approach. A secondary aim was to provide institutional legitimacy for young researchers (unrecognized until now because of their heterodoxy) from different scientific institutions (see Carrincazeaux et al. (2008) for more information on these scientific and institutional origins).

A special issue (no.3) of the Revue d'Economie Régionale et Urbaine in 1993 marked the group's official birth. It was the first result of their collective thinking, setting out the terms of what "proximity economics" could be, and proposing a new framework in the field of regional science, which at that time appeared "in crisis" (Bailly and Coffey, 1994). More generally, the proximity group was born from the theoretical aim to endogenize the territory within industrial dynamics by closely associating its spatial and productive determinants and by combining regional economics and industrial economics which until then had been mainly separated (Rallet and Torre, 1995). Research into industrial districts and innovative milieus opened up some interesting perspectives but raised two issues. First, when they exist, territories are considered as having intrinsic virtues and thus are studied through their positive effects. Second, this approach leads to overestimate the effects of local interactions relative to non local ones and makes clusters a near-exclusive model of local development. In the proximity approach, the territory is considered as the result of coordination between agents. It is built by socio-economic interactions, knowing that they are local or non local local. The objective is to study the local / non-local interactions mix that explains the geography of economic activities.

On this basis, the researchers proposed some original guidelines and presented a program of research with some strong issues in terms of public policies. The key question was to determine "to what extent innovation processes involve or do not involve a proximity relationship between the participating agents, given that there are two options: to territorialize or not to territorialize the relationship?" (Rallet, 1993). From the start, therefore, territorialized innovation policies were the main target for research, that is to say the regional and local dimension of technological policies.

\section{IN SEARCH OF AN ANALYTICAL FRAMEWORK}

The demonstration by the authors is based on the acknowledgment that there are many forms of proximity.

In line with the work by Perroux (1955), all the authors who declared that they were working on proximities agreed that alongside physical proximity, which "deals with separation in space and links in terms of distance", there was also a non-physical proximity which deals with "economic separation in space and links in terms of the organization of production" (Gilly and Torre, 2000, p. 12-13). They show that "being in proximity with someone does not only mean being near him/her, it might also mean having a strong complicity with a person 
who is geographically distant, whether that person belongs to the same circle of friends, family or even the same network of firms or professionals" (Rallet and Torre, 2004). There is a general consensus on the notion of geographic proximity, apart from the fact that using notions of geographic proximity, physical proximity or spatial proximity are open to discussion. Physical proximity is relative in two ways (Rallet and Torre, 2005), depending first on means of transport (transportation time and costs), and second on people's judgment of the distance. In order to operationalize this notion, Rallet (2000) clarifies it by saying that "agents are geographically close if they are able to meet on a daily basis".

Initially, highlighting non-spatial proximities (alongside spatial proximity) was more for methodological purposes. Rather than putting forward a theory, the more modest aim was to produce an analytical framework around the proximity concept in order to assess economic spaces in a new way. But researchers then tried to enrich the proximity concept by some theoretical references, possibly leading them to break down proximity differently. Thus a recurring theoretical debate took place between those supporting institutionalist approaches (Talbot, 2008; Gilly and Lung, 2008), who distinguished between institutional proximity and organizational proximity, and supporters of more interactionist approaches (Rallet and Torre, 2005; Pecqueur and Zimmermann, 2004), who broke down organized proximity into a rationale of similarity and of belonging. These distinctions reflect the different conceptual theories held by the authors (Torre, 2008). More recently, theoretical additions have been made to the initial proximist typologies (see the 2008 special issue of the RERU). Talbot (2008), belonging to the institutionalist trend, incorporates contributions by former institutionalists while Bouba-Olga and Grossetti (2008), generally considered as interactionists, propose a new typology of proximity which is essentially non-spatial and which they describe as socioeconomic proximity. Based mainly on studies of social embedding (see above), these latter authors do indeed show the presence, alongside physical proximity, of socioeconomic proximity, revealing the importance of the embeddedness of actors into their social and economic environment. Within this socioeconomic proximity, they distinguish a proximity of resources and a proximity of coordination. The question remains as to which proximity(ies) will be important for innovation, since operationalization of the different proximist typologies was fairly limited in the group's early period.

Alongside this theoretical debate, consideration is also given to the proximist typology, with a more operational objective. Some authors stress the ambiguity and the risks of overlap of the different types of proximity. In particular, Boschma (2005) stresses "the particularly vast notions of organizational and institutional proximities" (Boschma, 2004, p.21). He considers that "for analytical reasons, it is essential to clarify and define the different dimensions of proximity in such a way that overlap is avoided as much as possible, and research can assess the effects of each dimension" (p.62) and proposes to remove such limitations, "thanks to a fivefold classification of geographical, cognitive, social, institutional and organizational proximity". Cognitive proximity corresponds to the degree of convergence/overlap between the basic knowledge of two firms. Given the tacit, idiosyncratic and cumulative nature of knowledge, the greater the cognitive proximity, then the stronger the capacity for absorption of external knowledge and the possibility of innovation (Noteboom, 2000). Organizational proximity must be distinguished from the preceding one and is defined as "the extent to which relations are shared in an organizational arrangement, either within or between organizations" (Boschma, 2005, p.65). Coordination is facilitated and transaction costs reduced when knowledge is exchanged. Based on the literature on embedding (Polanyi, 
1944; Granovetter, 1985), social proximity refers to the social embedding of actors, to the existence of inter-individual social relations. Lastly, according to North (1990), institutional proximity indicates the macro-economic environment in which the firm is embedded. It corresponds to the rules of the game, the culture and values that actors share. These last two forms of proximity are a source of confidence that fosters knowledge exchange.

This analytical breakdown of proximity is described as evolutionist. ${ }^{7}$ According to the author, proximity categories are chosen and defined in such a way as to ensure that there is no overlap between them. ${ }^{8}$ By distinguishing the five forms of proximity analytically, it is then possible to introduce cognitive and social proximities while clarifying the other dimensions.

Despite the criticism leveled against this typology (see Bouba-Olga et al., 2014) and against those that preceded it, it did enable the proximist typology to become operational, it popularized approaches in terms of proximity and it widened the audience. Thus at the end of the 2000s, based on Boschma's typology (2005), many authors sought to evaluate the respective weight of the five categories of proximity in innovation processes. Figure 1.2 presents the scientific importance of this article since 2005, showing its increasing influence until the beginning of the 2010s, with a slight decrease over the recent period. According to Google Scholar, the article has been cited over 2,348 times in all since 2005, providing the author with a sizeable "citation capital" (Insel, 2009).

Figure 1.2: Scientific impact of Boschma's (2005) fivefold classification

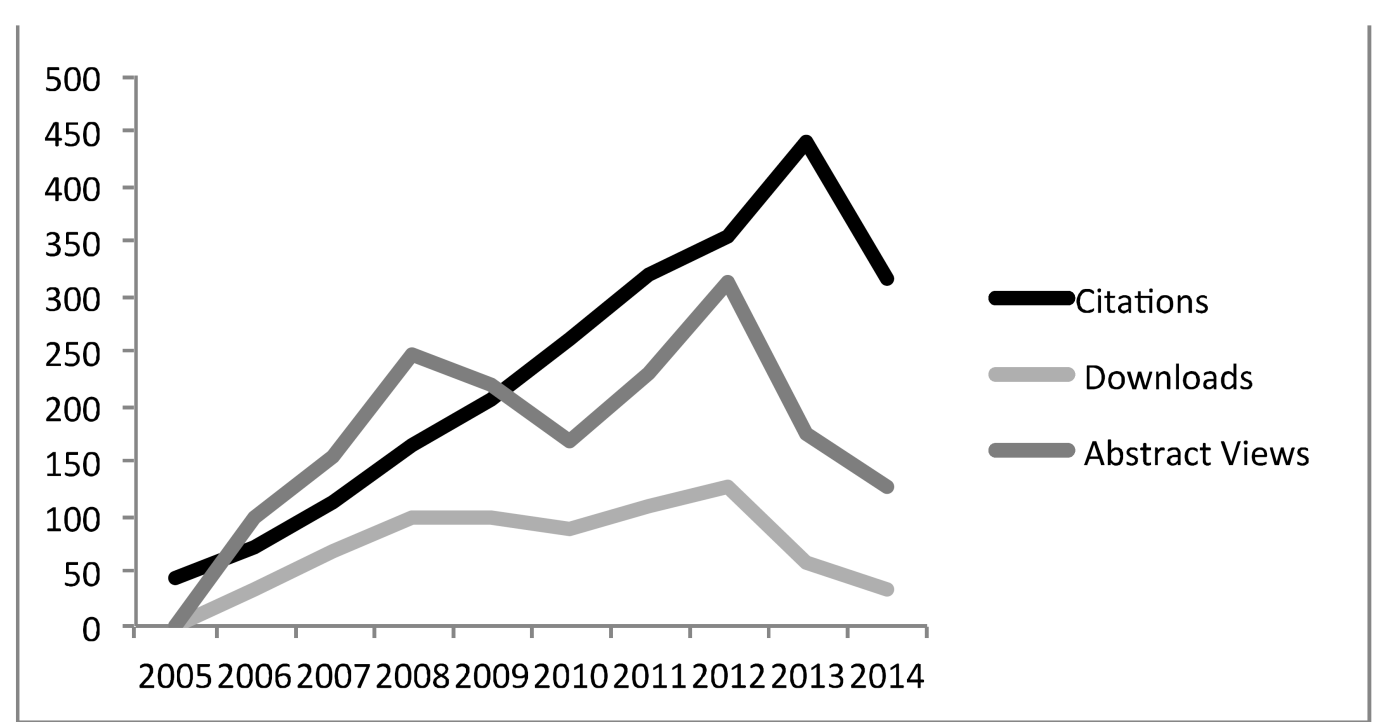

Source: Citation numbers from Google Scholar; downloads and abstract views from Repec (Nov., 2014)

In line with the positions of the proximist trend founders, Boschma (2005) claimed that geographical proximity is neither a necessary nor a sufficient condition for learning and innovation. In this and later articles (Boschma and Frenken, 2010) he adopted a critical stance on the general acceptance of the economic virtues of geographic proximity: too little and too much proximity may both harm performance (Boschma, 2005; Broekel and Meder, 2008). He developed the notion of a "proximity paradox" (Boschma and Frenken, 2010) where the "weak" version consists in showing that a high level of proximity is advantageous 
for bringing partners together, yet without affecting performance, and the "strong" version maintains that too much proximity can have a negative effect on company performance in terms of innovation. In the same way that Noteboom (2000) indicated for proximity/cognitive distance, Boschma and Frenken (2010) suggested the existence of an optimal level for the different forms of proximity. The different versions of the proximity paradox seem to be verified empirically. To illustrate this, Cassi and Plunket's results (2014) on patents in the genome sector show that while different forms of proximity encourage the formation of new collaborations, an increase in the degree of technological proximity reduces performance in terms of innovation, suggesting that there is an optimal level of proximity. Broekel and Boschma (2012) also demonstrate, in the aeronautics sector in the Netherlands, the positive influence of forms of proximity on the formation of a network, but they also show that too strong a cognitive proximity leads to inferior performances.

\section{LATER STUDIES TAKE TWO DIRECTIONS: EMBEDDEDNESS AND NETWORK MODELING}

During this second period, many advances were made in combining proximity and innovation. In this section, we focus on two major trends and two important contributions to the direction taken by research into proximity which affected its life cycle.

On the one hand, studies aimed to deepen the social foundations of the proximist typology for geography of innovation. In this respect, incorporating the embeddedness theory seemed to be productive and confirmed the idea that not everything can be explained by economics. On the other hand, research enhanced the analysis with a purely economic explanation and continued the search for operationalization and quantification of forms of proximity by network analysis.

\section{SOCIAL EMBEDDEDNESS}

By distinguishing between the various forms of proximity, different cases/situations could be categorized according to the overlapping of spatial and non-spatial proximities. This distinction also allows the authors to test the hypothesis that non-spatial proximities could explain the geographic proximity observed during the innovation process. Indeed some authors showed that the functional reasons (that is the need for face-to-face interactions and tacit knowledge exchange) that are supposed to explain the co-localization of economic agents involved in the same innovation process are not necessarily valid. The co-localisation - and more generally the territorialization of the innovation process - could be explained by external mechanisms, such as social embedding. In other words, territorializing collaborations for innovation could be explained at least in part by the existence of localbased interpersonal relations. Indeed, one route that we believe should be highlighted and which has helped move forward the analysis of coordinating actors and their relationship with the territory is that of social embeddedness. Michel Grossetti, a sociologist and founding member of the proximity group, stressed the importance of this notion from the beginning of the 2000s (that is to say social embeddedness could explain the geographic concentration of actors participating in innovation projects) and guided some of the proximity group's research in this direction.

The notion of embeddedness has its origins in studies inspired directly by the new economic sociology. As we know, in a famous article published in 1985, Mark Granovetter defended the theory that economic activities are dependent on the interpersonal relations in which 
the actors are involved, and described this dependence as embeddedness. This theory has several implications. First, economic activity is dependent on more general social structures, which are not social groups or categories but networks (Wellman and Berkowitz, 1988). Second, the relevant level of economic action is not that of firms or organizations in general, but that of individual actors and their relations.

Exchanges between firms and academic research laboratories and innovation relations generally have also been studied from the embeddedness theory standpoint. For example, Walter W. Powell, who worked in the biotechnology industry in California (Powell and Brantley, 1992), sought to show that "behind the formal links there are informal relations give them life, support them, and frame their development" (Powell and Smith-Doerr, 1994, p.384). The notion of embeddedness has also been applied in the context of the debate on the effects of spatial proximity. For many researchers these localized effects (already demonstrated particularly by Acs and Audretsch, 1988; Jaffe, 1989; Audretsch and Feldman, 1994; Mansfield, 1994, and many others) observed in innovation activities can be explained less by simple physical proximity and more by the growing importance of social networks in economic activity and the fact that for the most part these are local. Most existing studies show that social relations are more easily formed in the local neighborhood, "the greater the distance, the less contact and support" (Mok et al., 2007, p.434). Empirical studies (Wellman (1996) on a sample of Toronto inhabitants, Fischer (1982) on the population of San Francisco and Grossetti (2007) on Toulouse confirm that personal networks make up a significant share of local relations. This is also the case in studies inspired directly by the new economic sociology, like the article cited above by Powell and Brantley, or which refer to it explicitly, like that by Saxenian (1994), or by Ferrary and Granovetter (2009) on Silicon Valley. Michel Grossetti shows that few studies are available to verify that embedding collaboration in social networks can promote the construction of local partnerships.

Combining the notions of embeddedness and proximity, Michel Grossetti and Marie-Pierre Bès $(2001,2002)$ have sought to fill this gap. Using a mixed method called quantified narratives, the authors assessed the weight of the effects of embeddedness and spatial proximity in creating collaborations for innovation; they carried out numerous surveys on French research scientists, asking about their research relations with industrialists. In a more recent survey on start-ups, Grossetti et al. (2008) show the variable effect of different types of proximity according to the phases of the firm's development process; splitting the process into different stages, something which is still not commonly done, reveals in particular the importance of social embeddedness and hence of social proximity during the formative phase. These concepts and the analysis methodology were taken up by Ferru (2010) in the Poitou-Charentes region. She confirmed the significance of the methods used to coordinate innovation actors and the structuring role of social networks in the geography of innovation. A comparison of areas also reveals that social relations in the Poitou-Charentes region have a less local dimension, suggesting that innovation collaborations are also less local. A summary of these different empirical studies has been produced recently to underline certain consistencies when combining the effects of proximity and embeddedness (BoubaOlga et al., 2014). It shows that "the creation of relationships between organizations based on interpersonal relationships is an effect of inter-individual relational proximity on the relational proximity between organizations. This effect partly explains the effects of geographic proximity". It also recalls "the decisive role of the structural characteristics of territories in the geography of collaborations". Despite their many valid contributions however, we should note that studies on embeddedness can have a tendency to 
overestimate the significance of inter-individual relations in economic activity (in the same way as Polanyi overestimates market autonomy).

\section{ANALYSIS OF THE NETWORK AND MODELING}

Based on Boschma's proximist typology (2005), several authors, economists and geographers have enhanced the empirical approach by suggesting the use of network analysis to measure the significance of the five forms of proximity. "We claim social network analysis is a promising tool for empirically investigating the structure and evolution of interorganizational interaction and knowledge flows within and across regions" (Ter Wal and Boschma, 2009, p.739). As this tool does indeed seem to be promising, authors are using the relevant dynamic simulation models to formalize their analyses.

More specifically, in line with work on "small worlds" (Milgram, 1967; Watts and Strogatz, 1998), some authors describe and model interaction structures (Jackson, 2008, Carayol and Roux, 2009; Massard and Mehier, 2009) and show that networks structural features (density of weak links, average distance between two nodes, etc.) and the positioning of actors within the network (mainly via the concept of centrality) influence the performance of firms in general and their capacity for dissemination and absorption of knowledge in particular (Ahuja, 2000; Giuliani, 2007; Morrison, 2008; Steiner and Ploder, 2008). Since the late 2000s, proximist authors have shown a growing interest in network analysis, which they use to account for the formation of innovation networks and the different forms of proximity at work. Massard and Mehier (2009) "especially focus on the relational and strategic dimensions of proximity by using some developments from social network analysis" (p2) to explain accessibility to knowledge.

The Urban and Regional Research Center of Utrecht has been particularly active in the emergence and dissemination of this type of work, first with theoretical studies, with articles by Ter Wal (2009) and Boschma and Frenken (2010), then, more significantly with empirical studies. These authors are "geo-economists interested in the effects of homophilia (favoring the establishment of social relations or sharing information with those whose characteristics are similar to one's own) for example, to explain the effects of synergy observed in local innovation systems" (Maisonobe, 2013, p.2). They use geolocation databases of individuals and their inter-relations, from which they can identify collaboration networks and formalize network analysis. They explain the existence of social relations using the stochastic actorbased model SIENA (Snijders, 2001; Snijders et al., 2010). ${ }^{9}$

Thus in recent years, as highlighted by Maisonobe (2013), "the SIENA model has been highly prized by members of the Proximity School" as "this tool seems particularly well adapted to the treatment of the question of the relative importance of the different forms of proximity" (Ter Wal and Boschma, 2009). In the same vein, Balland (2010) says that "entry via relational data allows the role of proximity at the individual level to be appreciated and constitutes a promising avenue of research into the proximity role".

Balland et al. (2013a) have tested Boschma's (2005) proximist typology specifically in the videogame sector. Using a longitudinal database on the coproduction of videogames and an actor-oriented stochastic model, the authors studied how the five forms of proximity could potentially affect the formation of this collaboration network between 1997 and 2007. It appears that over time, firms in the videogame sector have a tendency to favor partners that are physically closest and which are most similar in cognitive terms, highlighting changes in the effects of proximity in the course of the life cycle of the network. Using a similar 
methodology and in an attempt to evaluate the role of different proximities in the formation of innovation networks, many empirical studies have been undertaken since the end of the 2000s (Balland, 2010; Broekel and Boschma 2012; Hardeman et al., 2012; Balland et al., 2013a; Ter Wal, 2013; Balland et al., 2013b; Wanzenbock et al., 2015; Boschma et al., 2014; Balland et al., 2015; etc.).

From these empirical studies we have learned that controlling non-spatial forms of proximity tends to diminish the role of geographic proximity when actors join a network. Some studies also test the substitutable or complementary nature of proximities in forming innovation networks. For example, Ponds et al. (2007) studied co-publications and show that geographic proximity can help overcome institutional differences between actors (university vs. industry). Cassi and Plunket (2015), on the other hand, show that geographic and social proximities have a similar role and are substitutable when forming collaborations.

In an evolutionist approach, a dynamic perspective is introduced into the analysis to show how the influence of proximities changes over time. Some empirical studies have looked at the importance of time via longitudinal databases (see especially Hoekman et al. (2010) and Balland et al. (2013a)); "but even though these works make an important step by looking at whether the type of proximity explaining collaboration changes over time, the static logic in proximity approaches is essentially maintained, as proximity remains the driver of tie formation, and no attention is paid to the question whether the latter affects the former" (Balland et al., 2015a). This dynamic perspective is covered in a theoretical article by Balland et al. (2015a) which recalls the importance of complex interactions between proximities and especially the possible pre-existence of non-spatial proximities and their effects on geographic proximity. Thus to avoid postulating a linear and unidirectional causality, "we propose a dynamic extension of the proximity framework of Boschma in which we account for co-evolutionary dynamics between knowledge networking and proximity. For each proximity dimension, we describe how proximities might increase over time as a result of past knowledge ties" (Balland et al., 2015a). In this way, a more realistic circular vision can be introduced. This co-evolution of proximities and knowledge networks happens when a long-term perspective is adopted, as proximities evolve less quickly than relations and networks. However, it is a complex task to validate this dynamic extension empirically and to measure interactions between all five forms of proximity.

This dynamic perspective requires a simplification of the forms of proximity. This, in our opinion, is the very reason for introducing the concepts of "related variety" and "relatedness" (Boschma and Frenken, 2011). By focusing on one form of proximity, cognitive proximity, these concepts ensure that it is possible to bring a dynamic perspective into proximity while removing the difficulties associated with incorporating the many possible interactions between the different proximity forms. ${ }^{10}$ This relatively recent literature plays a part in analyzing the geography of innovation and enhances the study of externalities and clusters by insisting on one form of proximity, cognitive proximity, as confirmed by the following definition: "we define related variety as sectors that are related in terms of shared or complementary competences. In other words, some degree of cognitive proximity is required to ensure that effective communication and interactive learning take place, although not too extreme, to avoid cognitive lock-in" (Boschma and lammarino, 2009, p.5). The concept of relatedness is even synonymous in some cases with cognitive proximity - a proximity on which Boschma (2005) placed particular emphasis (see above) - and is defined and measured on the basis of similarity between two products or elements of knowledge. ${ }^{11}$ Since 1999, Boschma had used these concepts "to identify clusters of innovative industries 
during the entire industrial period that were connected through dynamic processes of transfer and feedback of technology that crisscrossed a set of industries during a particular period" (Boschma, 2009, p.293). Boschma showed that "cognitive proximity between extraregional knowledge and the knowledge base of the region should be neither too small-avoiding lock-in in learning processes-nor too large-enabling the absorption of extraregional knowledge" (ibidem, p.295). The purpose of these studies was to explain why certain regions produce one specific type of knowledge rather than another and to show that new knowledge emerges when there is a solid base of pre-existing knowledge linked to it (Boschma and Frenken, 2011). Thus territorial dynamics and the geography of innovation would be fundamentally structured by their degree of technological/sectoral relatedness. Mobilizing these concepts would then be a way of identifying opportunities for territories in terms of innovation and their degree of technological resilience.

Effects linked to variety and/or sectoral and scientific relatedness have recently been measured in relation to geographic proximity, with Boschma et al. (2009) testing the effect of related competencies on a firm's growth and showing that this effect is modified when geographic proximity (regional recruitment) is included in the analysis. More precisely, they show that firms sector-relatedness has a greater impact than geographic proximity when carrying out merger-acquisitions. Ellwanger and Boschma (2013) refine this result using a database over a long period (in the Netherlands, at city level). They confirm the importance of sector-relatedness in the appearance of mergers and acquisitions, but they also show the positive influence of geographic proximity when it is measured at a very detailed level (municipalities).

The concept of relatedness links a firm's evolutionist approach, following on from Penrose (1959), to traditional industrial economic notions. It is indeed very similar to "technological proximity" or "knowledge proximity", terms that have been widely used since the 1980s to analyze R\&D spillovers (Jaffe, 1986), technological diversification in industry (Breschi et al., 2003, Cantwell and Vertova, 2004) and how these are linked to product diversification (Pavitt et al., 1989), with Griliches (1979) having been one of the pioneers in measuring R\&D externalities using technological proximity indicators.

\section{PROLIFERATION OF STUDIES}

The work developed by Boschma and his co-authors has proved useful in the methodological and empirical contribution it has made: in particular, they have made it possible to operationalize concepts of proximity. "The advantage of network analysis is that it can be applied to any kind of data indicating a relation between two actors" (Ter Wal and Boschma, 2011).

It is now possible and straightforward to duplicate this work as long as one has a sufficient quantity of dyadic data. Accordingly, "various kinds of data have been used to indicate knowledge networks" (Balland, 2014), including knowledge sharing relations (Giuliani and Bell, 2005; Giuliani, 2007; Morrison, 2008; Broekel and Boschma 2012), patent citations (Agrawal et al., 2006; Breschi and Lissoni, 2009), joint patents (Cantner and Graf, 2006; Hoekman et al. 2009), joint publications (Ponds et al. 2007, 2010; Frenken et al. 2009; Scherngell and $\mathrm{Hu}, 2011$; Hardeman et al. 2012) and joint participation in R\&D projects (Hagedoorn, 2002, Autant-Bernard et al. 2007; Maggioni et al. 2007; Scherngell and Barber 2009; Balland, 2012). Nevertheless, authors sometimes mention limitations associated with their data (Ter Wal and Boschma, 2011), pointing out that although interview data provide 
the most information, because interviews themselves are so time-consuming, it is impossible to obtain enough data extending over time and space (for more details on the limitations of data used to analyze a network, see Bernela and Levy (2015) discussing the virtually systematic hypothesis of complete graphs).

The proliferation of empirical studies applying the same model and the same methodology to different databases, yet which were accepted by peer-review, was a factor of enrichment but also one of saturation. It was enriching because the influence of proximities could be tested on different territories, time spans and sectors. However, the very repetitive nature of these studies eventually took the analysis down the path of diminishing returns. The method tended to take precedence over the aim of the research, the analysis, the network and over the model in general, in providing tools that could be re-used over a set of databases (see above). There was a risk of losing sight of the whole purpose of the work in progress. The conclusions that could be drawn in relation to public policies were too often redundant (the limited role of geographic proximity) or too difficult to use (cognitive proximity was especially influential in phase 2 in one sector of activity and in phase 3 in another, but what could be done with this information? Should one modify or reproduce this characteristic? Why and how?).

This accumulation of barely innovative statistical studies on a given subject is not specific to empirical research on proximity. It has unfortunately become something of the norm in academic circles. It illustrates the general phenomenon of researchers being increasingly subjected to the "publish or perish" rule, which impels them to produce work as quickly as possible, something which is easier to achieve with quantitative studies. The need to publish quickly and in great quantities (Fanelli, 2010; Parchomovsky, 2000) tends to standardize research strategies and encourage imitation (Insel, 2009) and hence research is repeated. This process does not favor a long-term scientific dynamic and emphasizes the need to bring in more intellectual creativity (Boyer, 2014).

The empirical literature on proximity, with its proliferation of articles and repetition of results, is not immune to this risk, which is why new avenues of research need to be explored.

\section{EXPLORING NEW AVENUES}

If we are to escape the problem of diminishing returns we must take risks and consider renewing subjects and methodologies, and pursuing some new avenues.

Here we put up three for discussion. They are by no means exhaustive, and others can be envisioned, as we suggest in the conclusion to the section.

\section{THE NEED TO TAKE REPRESENTATIONS OF PROXIMITY INTO ACCOUNT}

Rather than increasing the number of categories of proximity, with the risk of obscuring their inter-connections, the question of representations of proximity should be introduced. The proximity literature does tend to refer each category of proximity (geographic, relational, technological, etc.) to its own specific objectivity. It is this which makes it possible to design a location diagram in which relationships between various types of proximity are weighted. Each one has its own objective content (kms or time-km for geographic proximity, cocitations of patents for technological proximity, financial ties for organized proximity, etc.) which influences the geographic configuration of innovation activity to a greater or lesser 
extent. Searching for an objective measurement of proximities serves to exaggerate this phenomenon. Economic agents act not so much according to the objective content of this or that proximity category but rather according to their perception of it. This is particularly true of geographic proximity, which is related not only to objective data (distance-time) but also to agents perception of distance. Thus what is a distant relationship for some may appear as a close relationship for others and vice versa, with the result that the objective content of this distance is not necessarily significant for the proximity criterion.

The representation of proximity matters. For a long time, geographers have made use of this dimension of the mental perception of space, insisting on the differences between cognitive distance and real distance (see, for example, the summary review in Behavioral Geography produced 30 years ago by Bailly, 1985). This amounts to saying that geographic proximity is itself pluralistic and that it must be taken into account in order to know what part it plays in explaining the spatial forms of innovation processes. Aguiléra et al. (2014) define 3 forms of geographic proximity from completed questionnaires sent to 2000 Breton SMEs on their relations with their main business partner. One, called "real proximity" is objective (kilometer thresholds), the other 2 are subjective: "perceived proximity" is whether the firm has the impression that it is spatially close to its main partner; "active proximity", a subcategory of "perceived proximity", is when the firm says that spatial proximity has been instrumental in facilitating exchanges with the partner. It is interesting to observe the discrepancies between these three spatial proximities. It was noted that 33 per cent of firms located less than $50 \mathrm{kms}$ from their partner said that proximity had not played a facilitating role, while 30 per cent of firms located further away (and sometimes at international level) believed that proximity did play a part. Thus, perceived proximity can exist without it being active. As well as requiring explanation, these differences between real, perceived and active proximities show that any hasty assimilation need to be reassessed.

Thus, in the literature, geographic proximity is assimilated with the existence of interactions: it is because agents are located close together that they are able to interact face to face. Aguiléra et al. (2014) turn the proposition around: it is because agents have social interactions (face to face relations) that they feel geographically close. This article shows that real proximity is only perceived and is certainly only active for firms that have face to face relations with their partner. Yet in the literature, it is futile to raise questions about the connection between geographic proximity and face to face relations as these two terms are equivalent; in fact, the type of social interaction determines the perception of geographic proximity and its activation.

With the representation of spatial proximity counting for more than proximity itself, what are its determinants? Studies carried out over the last 25 years seem to show that these determinants are organizational, relational and institutional interactions. Organizational through firms modes of organization, relational through embeddedness in social networks, and institutional through the effects of proximity created by public policies. It is they that skew and shape our perceptions of spatial proximity through the routines and cognitive maps that they put in place. While the literature often takes as its starting point what geographic proximity does or does not allow when faced with other proximities, the real question is rather: in what way do interactions - organizations, social networks and institutions - create geographic proximity in economic activities and in this case in innovation processes? From the moment that geographic proximity ceases to be a strictly physical objectivity and also becomes a representation, it can no longer be considered as a 
prime factor to account for geographic patterns as it is responding to social determinants (see above).

\section{NEW PERCEPTIONS OF SPACE-TIME: WHAT ARE THE CONSEQUENCES FOR STUDIES ON PROXIMITY?}

Studies on economic geography and proximity economics argue implicitly within the framework of a physical economy (legacy from the $19^{\text {th }}$ century) steeped in knowledge (legacy from the $20^{\text {th }}$ century). Space is identified as a set of places where agents are located, between whom various types of externalities develop, each with a different spatial influence, and where reasoned development lies at the heart of innovation policies. However, two dimensions in this world have already changed.

First, spatial scales are no longer what they used to be: globalization affects not only the financing, design and creation of innovation but also the opportunities it opens up. Whereas previously, it was possible to innovate in a local context and extend this framework gradually in successive stages, now the world's frame of reference levelled out: spatial scales remain, but the reference space has immediately become intrinsically global.

There is a simultaneity in spatial scales: agents must work at different spatial levels at the same time. The register in which they act has been transformed, as has the way in which it is represented. Basically, the "geographic proximity versus non-geographic proximities" question, which had been the founding issue of the Proximity School, assumed that a local action register was possible, a register crossed by non-geographic modes of coordination (the other proximities). Today, however, an agent must establish and coordinate his action simultaneously at several spatial scales (local, regional, national, international). He is both "here and elsewhere". This is what we call an agent who is "situated" rather than an agent who is "located", who is "here or elsewhere" in space (Rallet and Torre, 2004). Local is no longer a form of territorialized economic activity as opposed to a deterritorialized form, but is rather a territorial application of a global process. Geographic proximity relations are inseparable from global relations. They have to be considered as being part of the same spatial set and not as opposing territorial forms. A locally embedded cluster cannot be understood without being inserted into a global economy. Support policies for clusters recognize this but in practice they value local synergies unilaterally. Methodologies for evaluating clusters underestimate and sometimes ignore the role of global relations by taking into account only local interactions.

In this context, one might ask whether maintaining the "geographic proximity versus other proximities" issue still has any meaning.

There is another transformation to take into account in our space-time relationship. Agents must not only situate their action at various spatial levels, but they must also be mobile. They are not necessarily where they were thought to be, that is to say allocated to fixed locations. The presence in space of a researcher or an engineer must not be confused with the location of the establishment to which he belongs. This presence becomes multiform, occupying various places: another partner establishment, a transitional place such as a conference or a meeting, an intermediate urban location (a "third place"), etc. In other words, there is a transitional mobility that has to be considered, which is different from the mobility that consists of substituting one fixed location for another fixed location. This form of mobility is growing rapidly, driven by the joint impetus from transportation and communication. A significant proportion of the population is not affected, but it plays an 
increasing role in coordinating agents, as it is their means of temporary proximity (Rallet and Torre, 2005, Bathelt and Schuldt, 2008), especially in the field of innovation. Geographic proximity in space can therefore be achieved in some very different ways: permanent colocation, transfer for a certain length of time to a partner establishment, periodic or occasional meetings in intermediate places, etc. Temporary proximity blurs the maps of agents apparent locations while being very difficult to measure statistically. It has to be taken into account, however, and its impacts on the analysis of proximities analyzed.

Having a multi-scale approach and taking temporary proximity into account are all the more important as innovation processes have become more complex and cannot be represented simplistically (here versus elsewhere, local versus global). Firms and research centers carry out various innovation projects simultaneously, with partners that are themselves different, and which are located at different spatial scales. Hence the following hypothesis: the location of a research unit (and its partners) is less important than the ability to start from a place and combine different spatial scales with different partners using means of communication (men and information) and societal supports (social networks, professional communities, etc.). Innovation is based on the organization and management of a variable portfolio of relations with partners. By definition, it is impossible to manage this flexibility by reasoning in terms of location, that is to say being physically anchored (an optimal location at time $t$ will no longer be so at time $t+1)$. It is the ability to combine different spatial scales which is important. Places continue to be important, but through the material possibilities that they offer agents to be able to combine the various spatial scales of their partnership relations: transportation and communication, professional connectivity platforms, infrastructure for meetings (trade exhibitions, fairs, third places, co-working areas, etc.), etc. Public policies must take this aspect into account.

\section{THE RESILIENCE OF CLUSTERS AND THE RETURN OF TERRITORIES}

The ability of geographic clusters to reinvent themselves and to endure over time is a question that has long been discussed (Courlet and Dimou, 1995). It has had renewed attention in recent years. On the one hand, researchers into proximity attach great importance to problems of long dynamics and the evolutionist approach that is used to understand them. On the other hand, a key issue for clusters is to be aware of the factors that will enable them to escape diminishing returns and the effects of lock-in.

There are several possible ways to achieve this. The first arises from the need, as already pointed out, to move to a dynamic approach to the interconnections between various types of proximity, in order to avoid an over-determination of one type by another. Over time, the different forms of proximity co-evolve and are linked one to one another, taking on more significance in certain phases of the dynamics studied. Searching for the most important form of proximity becomes a complex and somewhat futile exercise as the number of categories of proximity used increases (see above). Another way of dealing with the dynamics of clusters is to explain points of bifurcation within the development trajectories of innovation networks (Suire and Vicente, 2009; Menzel and Fornahl, 2009; Crespo et al., 2014; Boschma and Fornahl, 2011; Crespo, 2011; Suire and Vicente, 2009, 2013; Neffke et al., 2010, etc.). Some of this literature overlaps the approach in terms of relatedness (Boschma, 2014; Crespo et al., 2014). Crespo et al. (2014) and Suire and Vicente (2013) have modernized the approach by using network analysis. They try to pull out the structural properties of networks, pairs of terms in fact (information externalities versus network 
externalities, hierarchy/assortativity, exhaustion/resilience), which determine cluster development. Structural indicators can be deduced from this to guide public policies. These indicators remain descriptive of a reality but without being able to explain its complexity and in fact these studies do not clarify the territorial dynamics that lie behind the clusters. The analysis deals with clusters by considering them as formal network structures rather than as territorialized forms of innovation. These studies need further work done on them, using qualitative data obtained from field work in order to interpret the value of the indicators obtained. It would seem necessary and even essential to go back to the territory in order to go further with the analysis.

To revisit the question of the territorial anchoring of the clusters, we suggest two avenues of research, which presuppose a return to the notion of territory in industrial analysis. The first is based on the fact that nowadays innovations are born within ecosystems with a large territorial dimension. The notion of an ecosystem is much broader than that of a cluster: it includes non-industrial actors (consumers, communities, etc.) alongside the industrial and institutional actors, which makes them more heterogeneous and creates many coordination problems before any innovation, which can be particularly disruptive, reaches the market. Territorial anchoring stems from the fact that local experiments are required to resolve these coordination problems and shape the ecosystem, with public policies supporting these experiments. The second avenue relates to the conditions in which creativity is able to emerge and reproduce in a territory. The creativity on which innovation ultimately depends is not intrinsic to a territory; it depends on the way in which a territory is organized. In the example of the Montreal video game analyzed by Cohendet et al. (2013), creativity is linked to the ability of an intermediate layer (concert halls, various third places) to connect an underground layer of the city (street artists, video practices by amateurs, etc.) to its business, or upper ground layer (major studios, video game publishers, etc.). The territorial anchoring of innovation stems from the fact that urban proximity is a connector of different worlds.

As we pointed out at the beginning of this section, other avenues can be suggested. For example, few studies on proximity use organization theories to analyze the impact of organizational choices on the spatial distribution of innovation activity. The issue has mainly been approached from the standpoint of the functional coordination of innovation processes (for example, is physical proximity necessary to participate in such-and-such a phase of the innovation process?) or we have simply settled for a vague notion of organizational proximity. Organizational procedures must be given in detail, with each type of procedure (coordination, supervision, inspection, incentives, etc.) being analyzed with reference to whether or not it is able to produce forms of distance working when used in combination with technical supports (standards, certifications, communication technology, etc.). This work has not been developed because organizational economists or sociologists have shown little interest in the spatial dimension of organizations. In the area of innovation, there is an interesting question: how do new organizational choices related to product and service innovation (open innovation, co-innovation, etc.) impact on the spatial configuration of the innovation process?

\section{CONCLUSION}

So what can we conclude in relation to the question posed in the title of this article where we announced a review of a research trend started 25 years ago in the field of geography of innovation? 
It seems indisputable to us that returns are indeed diminishing. Output from studies in this field continues to be positive but is now of relatively minor importance. Minor in terms of intrinsic results (results are repetitive) and minor in terms of new lessons learned from these studies for public policies (but here repetition can have educational value). This will not prevent such studies from continuing. First of all, researchers will find new databases and/or new methodologies with which to verify or extend previous work. Second, the pressure to publish or perish will be an incentive to continue along this path as it is always easier to publish a standard paper on a recognized topic than to open up new areas of research.

Diminishing returns are explained primarily by the fact that the research program launched 25 years ago has largely achieved its objectives. Remember that its purpose was to challenge the supposed virtues of geographic proximity with regard to innovation activities and to reinstate these activities in a broader vision of the space where local and non-local relations are linked together. The analysis framework proposed in the 2000 s gave rise to a number of empirical studies which have largely shown the relative role played by geographic proximity and the importance of other essentially non-geographic proximities as supports for coordinating innovation activities. The public authorities still have to be convinced, but this is starting to happen and it tends to consist more of marketing work carried out rather than new research. Nevertheless, the transfer of knowledge to political bodies is crucial as it is being done too late and requires particular attention, to which researchers attach too little importance.

Avoiding diminishing returns, that is to say an accumulation of studies which make only a minor contribution, requires conceptual creativity. In section 4 we have outlined some ideas for renewal. They need to be clarified and there are certainly others to consider. Their common feature is that they move us away from the initial problem of the various types of proximity which provides no basis for answering the questions posed.

Finally, the proximity framework can be usefully extended to other fields, in addition to the geography of innovation (Torre and Wallet, 2014), but that is another issue altogether.

Generally speaking, we advocate a return to a conceptual questioning, where qualitative analyses enable us to explore new questions and quantitative analyses constructed around new problems. This is what was done 25 years ago, when the Proximity group was founded, and it is probably what must be done if we are to restart a research dynamic with increasing returns. Issues surrounding the geography of innovation are certainly far from being fully exploited.

\section{Notes}

1 See, for example, "Approches multiformes de la proximité" (Bellet et al., 1998), "La ville ou la proximité organisée", (Huriot (ed.), 1998), "Dynamiques de Proximité" (Gilly and Torre, 2000), "Économie de proximités" (Pecqueur and Zimmermann, 2004), "Quelles proximités pour innover ?" (Rallet and Torre, 2007), "La proximité à l'épreuve des technologies de communication" (Rallet and Torre, 2007), "Les Nouvelles proximités urbaines" (Rallet and Torre, 2008) and also "Regional Development and Proximity Relations" (Torre and Wallet, 2014).

2 https://eurolio.univ-st-etienne.fr

${ }^{3}$ Already in 2008, Carrincazeaux et al. stressed that "many monographs have made it possible to validate the theoretical conceptualization of proximities but this type of empirical approach is generally taken with caution within the social scientists'community". 
${ }^{4}$ Since 2008, Bouba-Olga et al. have also reflected on the future of the research group and its concerns, "Proximity, 15 more years? (...) one of the first challenges will certainly be to maintain the quality of the theoretical debates which have enhanced our meetings and will continue to do so (...) this will be achieved through contributions from beyond our borders".

${ }^{5}$ European Planning Studies (2008, $\mathrm{n}^{\circ} 5$, "Clusters, proximities and networks") and Revue d'Economie Régionale et Urbaine (2008, n³, "La proximité : 15 ans déjà")

${ }^{6}$ Groupe de Recherche sur les Milieux Innovateurs (Research Group on Innovative Environments) created in 1984 by Philippe Aydalot and directed by Roberto Camagni and Denis Maillat.

7 "The concept of proximity in five dimensions as defined by Boschma (2005) can thus be regarded as an extension of the evolutionary approach that focuses on cognitive proximity primarily: proximity is required in some (but not necessarily all) dimensions to get firms connected and to enable interactive learning and innovation among them" (Boschma and Frenken, 2009, .121).

${ }^{8}$ However, let us note that the risk of overlap increases with the number of proximities taken into account. In a dynamic perspective, the risk is all the greater when proximities are co-produced in time, so that it becomes difficult and a little futile to separate the influence of this or that form of proximity.

${ }^{9}$ Simulation Investigation for Empirical Network Analysis

${ }^{10}$ By focusing on one form of proximity, a dynamic perspective can be incorporated. This is also a constraint as it limits the analysis to one form of proximity, implying that some authors demonstrate the need to bring the literature closer in terms of relatedness to the proximist approaches (see Balland, 2015b).

${ }^{11}$ In other instances, it is defined and measured based on the complementary nature of products or knowledge. This duality of definitions is clearly expressed in an article by Ellwanger and Boschma (2013) where the authors define the industrial "connection" as referring both to similar or complementary economic activities.

\section{References}

Acs, ZJ. and DB. Audretsch (1988), 'Innovation in Large and Small Firms: An Empirical Analysis', American Economic Review, 78 (4), 678-90.

Aguiléra, A., Lethiais, V. and A. Rallet (2014), 'Le télétravail : sortir de l'impasse', Métropolitiques, 8 décembre

Agrawal, S., Davidson, N. and M. Walker (2006), 'Assessing the total costs of blood delivery to hospital oncology and haematology patients', Curr Med Res Opin, 22 (10), 1903-1909.

Ahuja, G. (2000), 'Collaboration networks, structural holes, and innovation: a longitudinal study', Administrative Science Quarterly, 45, 425-55.

Audretsch, D. and M. Feldman (1994), 'R\&D spillovers and the geography of innovation and production', Discussion Paper, FS IV (2), Berlin.

Autant-Bernard, C., Billand, P. and N. Massard (2007), 'Social distance versus spatial distance In R \& D cooperation: Empirical evidence from European collaboration choices in micro and nanotechnologies', Papers In Regional Science, 86 (3), 495-519.

Bailly, AS. (1985), 'Distances et espaces: vingt ans de géographie des représentations', L'espace géographique, 3, 197-205. 
Bailly, AS. and WJ. Coffey (1994), 'Regional science in crisis : a plea for a more open and relevant approach', Paper in Regional Science, 73, 3-14.

Balland, PA. (2012), 'Proximity and the evolution of collaboration networks: evidence from research and development projects within the global navigation satellite system (GNSS) industry', Regional Studies, 46 (6), 741-756.

Balland, PA., De Vaan, M. and R. Boschma, 2013a, 'The dynamics of interfirm networks along the industry life cycle: the case of the global video game, industry, 1987-2007', Journal of Economic Geography, 13 (5), 741-765.

Balland, PA., Suire, R. and J. Vicente, 2013b, 'Structural and geographical patterns of knowledge networks in emerging technological standards: evidence from the European GNSS industry', Economics of Innovation and New Technology, 22 (1), 47-72.

Balland, PA., Boschma, R. and K. Frenken, 2015a, "Proximity and innovation: from statics to dynamics", Regional Studies, forthcoming.

Balland, PA., Rigby, D. and R. Boschma, 2015b, 'The Technological Resilience of U.S. Cities', Papers in Evolutionary Economic Geography (PEEG), 1419.

Bathelt, H. and N. Schuldt (2008), 'Between Luminaires and Meat Grinders: International Trade Fairs as Temporary Clusters', Regional Studies, 42, 853-868.

Belis-Bergouignan, MC., 1997, 'Coopérations inter-firmes en R\&D et contrainte de proximité : le cas de l'industrie pharmaceutique', Revue d'Economie Industrielle, $\mathbf{8 1 .}$

Bellet, Michel, Kirat, Thierry and Christine Largeron (1998), Approches multiformes de la proximité, Paris : Coll Hermes.

Benko, Georges (1998), La science régionale, Paris: Presses Universitaires de France.

Bernela, B. and R. Levy (2015), 'Collaboration networks within a French cluster: do partners really interact with each other ?', Papers in Regional Science, forthcoming.

Boschma, R., 2004, 'Proximité et innovation ', Economie Rurale, 280, 8-24.

Boschma, R., 2005, 'Proximity and innovation: a critical assessment ', Regional studies, 39 (1), 61-74.

Boschma, R. and S. lammarino (2009), 'Related Variety, Trade Linkages, and Regional Growth in Italy', Economic Geography, 85 (3), 289-311.

Boschma, R., Eriksson, R. and U. Lindgren (2009), 'How does labour mobility affect the performance of plants? The importance of relatedness and geographical proximity', Journal of Economic Geography, 9, 169-190.

Boschma Ron and Koen Frenken (2010), 'The spatial evolution of innovation networks. A proximity perspective', in Ron Boschma and Ron Martin (eds.), Handbook of Evolutionary Economic Geography, pp. 120-125.

Boschma, R. and K. Frenken (2011), 'The emerging empirics of evolutionary economic geography', Journal of Economic Geography, 11 (2), 295-307.

Boschma, R. and D. Fornahl (2011), 'Cluster evolution and a roadmap for future research', Regional Studies, 45 (10), 1295-1298.

Boschma, R., Heimeriks, G. and PA. Balland (2014), 'Scientific knowledge dynamics and relatedness in biotech cities, Research Policy, 43 (1), 107-114.

Bouba-Olga, Olivier, Grossetti, Michel and Marie Ferru (2014), 'How I Met my Partner: Reconsidering Proximities', in André Torre and Frédéric Wallet (eds), Regional development and proximity relation, Edward Elgar, pp. 223-239.

Bouba-Olga, O., Carrincazeaux, C. and M. Coris (2008), 'La proximité : 15 ans déjà !', Revue d'Economie Régionale et Urbaine, 3, 279-287. 
Bouba-Olga, O. and M. Grossetti (2008), Socio-économie de proximité, Revue d'Economie Regionale et Urbaine, 3, 311-328.

Boyer, R., 2014, 'L'économie peut-elle (re)devenir une science sociale ? À propos des relations entre économie et histoire', Revue Française de Socio-Économie, 1 (13), 207-223.

Breschi, S., Lissoni, F. and F. Malerba (2003). Knowledge-relatedness in firm technological diversification, Research Policy, 32, 69-87.

Breschi, S. and F. Lissoni (2009), 'Mobility of inventors and networks of collaboration: An anatomy of localised knowledge flows', Journal of Economic Geography, 9 (4), 439-468.

Broekel, T. and R. Boschma (2012), 'Knowledge networks in the Dutch aviation industry: the proximity paradox', Journal of Economic Geography, 12 (2), 409-433.

Broekel, T. and A. Meder (2008) "The Bright and Dark Side of Cooperation for Regional Innovation Performance", Jena Economic Research Papers, 53.

Cantner, U. and H. Graf (2006) 'The network of innovators In Jena: an application of social network analysis', Research Policy, 35, 463-480.

Cantwell, J. and G. Vertova (2004), 'Historical evolution of technological diversification', Research Policy, 33, 511-529.

Cassi, L. and A. Plunket (2015), 'Research collaboration in co-inventor networks: combining closure, bridging and proximities', Regional Studies, 49 (6), 1-19.

Cassi, L. and A. Plunket (2014), 'Proximity, network formation and inventive performance: in search of the proximity paradox', The Annals of Regional Science, 53 (2), 395-422.

Carayol, N. and P. Roux (2009), 'Knowledge flows and the geography of networks. A strategic model of small world formation', Journal of Economic Behavior and Organization, 71, 414427.

Carrincazeaux, C., Lung, Y. and J. Vicente, 2008, 'The Scientific Trajectory of the French School of Proximity: Interaction- and Institution-based Approaches to Regional Innovation Systems', European Planning Studies, 16, 617-28.

Cohendet, P., Mehouachi, C. and L. Simon (2013), 'Managing the interplays of exploration and exploitation in the video game industry', paper presented at Séminaire de recherche, MOSAIC, HEC Montréal, 27 Juin.

Courlet, Claude and Michel Dimou (1995), 'Les systèmes localisés de production: une approche de la dynamique longue', in Alain Rallet and André Torre (eds), Économie industrielle et économie spatiale, Paris, Economica.

Crespo, J. (2011), 'How emergence conditions of technological clusters affect their viability? Theoretical perspectives on cluster life cycles', European Planning Studies, 19 (12), 20252046.

Crespo, J., Suire, R. and J. Vicente (2014), 'Lock-in or lock-out? How structural properties of knowledge networks affect regional resilience', Journal of Economic Geography, 14 (1), 199219.

Dupuy, Claude and Antje Burmeister (2003), Entreprises et territoires, les nouveaux enjeux de la proximité, Paris : La Documentation Française.

Ellwanger, N., and R. Boschma (2013), 'Who acquires whom? The role of geographical proximity and industrial relatedness in Dutch domestic M\&As between 2002 and 2008', Papers in Evolutionary Economic Geography (PEEG), 1319.

Fanelli, D. (2010), "Do Pressures to Publish Increase Scientists'Bias? An Empirical Support from US States Data", PLOS ONE, 5 (4). 
Ferru, M. (2010), 'Formation process and geography of science-industry partnerships: the case of the University of Poitiers', Industry and Innovation, 17 (6), 531-549.

Ferrary, M. and M. Granovetter (2009), 'The role of venture capital firms in Silicon Valley's complex innovation network', Economy and Society, 38 (2), 326-359.

Gilly, Jean-Pierre and Yannick Lung (2008), 'Proximités, secteurs et territoires ', in Catherine Laurent and Christian Du Tertre (eds), Secteurs et territoires dans les régulations émergentes, L'Harmattan.

Gilly Jean-Pierre and André Torre (2000), Dynamiques de proximité, Paris: L'Harmattan.

Giuliani, E. and M. Bell (2005), 'The micro-determinants of meso-level learning and innovation: evidence from a Chilean wine cluster', Research Policy, 34 (1), 47-68.

Giuliani, E. (2007), 'The selective nature of knowledge networks In clusters: evidence from the wine industry', Journal of Economic Geography, 7, 139-168.

Granovetter, M. (1985), 'Economic action and social structures: the problem of embeddedness ', American journal of sociology, 91 (3), 481-510.

Griliches, Z. (1979), 'Issues in Assessing the Contribution of Research and Development to Productivity Growth', Bell Journal of Economics, 10, 92-116.

Grossetti, M. and MP. Bès (2001), 'Encastrements et découplages dans les relations scienceindustrie', Revue Française de Sociologie, 42 (2), 327-355.

Grossetti, M. and MP. Bès (2002), 'Proximité spatiale et relations science-industrie : savoirs tacites ou encastrement (Polanyi ou Polanyi)', Revue d'Economie Régionale et Urbaine, 5 (2), 777-788.

Grossetti, M. (2007), 'Are French networks different?', Social Networks, 29 (3), 391-404.

Grossetti, M., Barthe JF. and E. Beslay (2008), 'Choix de localisation et mobilisation des ressources dans la création d'entreprises innovantes', Géographie, Economie, Société, 10 (1), 43-60.

Hagedoorn, J. (2002), 'Inter-firm R\&D partnerships: an overview of major trends and patterns since 1960', Research Policy, 314, 477-492.

Hardeman, S., Frenken, K., Nomaler, Ö. and A. Ter Wal (2012), A proximity approach to territorial science systems, paper presented at the EUROLIO Conference on Geography of Innovation, Saint- Etienne, France, January 24-26.

Hoekman, J., Frenken, K. and FG. Van Oort (2009) 'The geography of collaborative knowledge production in Europe', Annals of Regional Science, 43 (3), 721-738.

Hoekman, J., Frenken, K., and R.J.W. Tijssen (2010), 'Research collaboration at a distance: Changing spatial patterns of scientific collaboration within Europ', Research Policy, 39 (5), 662-673.

Huriot, Jean-Marie (1998), La ville ou la proximité organisée, Paris : éditions Anthropos.

Insel, A. (2009), 'Publish or Perish!', Revue du MAUSS, 1 (33), 141-153.

Jackson, Matthew (2008), Social and Economic Networks, Princeton University Press.

Jaffe, A. (1986), 'Technological Opportunity and Spillovers of R\&D: Evidence from Firm's Patents, Profits and Market Value', American Economic Review, 76 (5), 984-1001.

Jaffe, A. (1989), 'Real effects of academic research', The American Economic Review, 795, 957-970.

Lorentzen, A. (2007) 'The spatial dimension of innovation. Embedding proximity In socioeconomic space', paper presented at the Conference European network for industrial policy. Maggioni, M., Nosvelli, M. and T.A. Uberti (2007), 'Space versus networks in the geography of innovation: A European analysis', Papers in Regional Science, 86, 471-493. 
Maisonobe, M. (2013), 'Analyse dynamique et longitudinale des réseaux', accessed at https://halshs.archives-ouvertes.fr/halshs-00811672

Massard, N. and S. Mehier (2009), 'Proximity and innovation through an 'accessibility to knowledge lens', Regional Studies, 43 (1), 77-88.

Mansfield, P. (1994), 'Continuum strong-coupling expansion of Yang-Mills theory: quark confinement and infra-red slavery', Nuclear Physics, 418 (1-2), 113-130.

Menzel, M. and D. Fornahl (2009), 'Cluster life cycles-dimensions and rationales of cluster evolution, Lock-in or lock-out?', Industrial and Corporate Change, 19, 205-238.

Milgram, S., 1967, 'The Small World Problem', Psychology Today, 1, 62-67.

Morrison, A., 2008, 'Gatekeepers of knowledge within industrial districts: who they are, how they interact', Regional Studies, 42, 817-835.

Neffke, F., Svensso,n M., Boschma R., Lundquist KJ., and LO. Olander (2010), 'The Dynamics of Agglomeration Externalities along the Life Cycle of Industries', Regional Studies.

North Douglass (1990), Institutions, Institutional Change and Economic Performance, Cambridge University Press.

Parchomovsky, G. (2000), 'Publish or Perish', Michigan Law Review, 98 (4), 926-952.

Pavitt, K., Robson, M. and J. Townsend (1989), Technological accumulation, diversification and organisation in UK companies, 1945-1983, Management Science, 35 (1), 81-99.

Pecqueur, Bernard and Jean-Benoit Zimmermann (2004), Economie de proximité, Paris: Lavoisier.

Penrose, Edith (1959), The theory of the growth of the firm, Oxford: Basil Blackwell.

Perroux, F. (1955), 'Note sur la notion de pôle de croissance', Economie appliquée, 8, 307320.

Polanyi, Karl (1944), La Grande Transformation, Paris: Gallimard.

Ponds, R., Van Oort, F. and K. Frenken (2007), 'The geographical and institutional proximity of research collaboration', Regional Science, 86 (3), 423-443.

Ponds, R., Van Oort, F.G. and K. Frenken (2010), 'Innovation, spillovers and universityindustry collaboration: An extended knowledge production function approach', Journal of Economic Geography, 10 (2), 231-255.

Powell, Walter and Peter Brantley (1992), 'Competitive cooperation in biotechnology: learning through networks?', in Nitin Nohria and Robert Eccles (eds), Networks and organizations: structure, form and action, Boston : Harvard Business School Press, pp. 366394.

Powell, Walter and Laurel Smith-Doerr (1994), 'Networks and economic life', in Neil J. Smelser and Richard Swedberg (eds), The Handbook of economic sociology, Princeton: Russel Sage Foundation, pp. 368-402.

Suire, R. and J. Vicente (2009), 'Why Do Some Places Succeed When Others Decline? A Social Interaction Model of Cluster Viability', Journal of Economic Geography, 9 (3), 381-404.

Suire, R. and J. Vicente (2013), 'Clusters for life or life cycles of clusters: In search for the critical factors of clusters resilience', Entrepreneurship and Regional Development, 26 (1-2), 142-164.

Snijders, T. (2001), 'The Statistical Evaluation of Social Network Dynamics', Sociological Methodology, 31 (1), 361-395.

Snijders, T., van de Bunt G., and C. Steglich (2010), 'Introduction to actor-based models for network dynamics', Social Networks, 32, 44-60. 
Rallet, A. (1993), 'Choix de proximité et processus d'innovation technologique', Revue d'Économie Régionale et Urbaine, 3, 365-386.

Rallet, Alain (2000), 'De la globalisation à la proximité géographique : pour un programme de recherche', in Jean-Pierre Gilly and André Torre (eds), Dynamiques de proximités, Paris : Ed. L'Harmattan, pp.37-58.

Rallet Alain and André Torre (1995), Economie industrielle et économie spatiale, Paris: Ed. Economica.

Rallet, A. and A. Torre (2005), 'Proximity and Localization', Regional Studies, 39, 47-59.

Rallet, A. and A. Torre (2001), 'Proximité Géographique ou Proximité Organisationnelle ? Une analyse spatiale des coopérations technologiques dans les réseaux localisés d'innovation', Economie Appliquée, LIV (1), 147-171.

Rallet, A. and A. Torre (2004), 'Proximité et localisation', Economie rurale, 280, 25-41.

Rallet Alain and André Torre (2007), 'La proximité à l'épreuve des technologies de communication', Paris : L'Harmattan.

Rallet, Alain and André Torre (2007), Quelle proximité pour innover ?, Paris : L'Harmattan.

Rallet, Alain and André Torre (2008), Les Nouvelles proximités Urbaines, Paris : L'Harmattan Collection Géographies en Liberté, Paris.

Saxenian, AnnaLee (1994), Regional advantage: culture and competition In Silicon Valley and Route 128, Cambridge: Harvard University Press.

Steiner, M. and M. Ploder (2008), 'Structure and strategy within heterogeneity: multiple dimensions of regional networking', Regional Studies, 42, 793-815.

Scherngell, T. and M.J. Barber (2009), 'Spatial interaction modelling of cross-region R\&D collaborations. Empirical evidence from the 5th EU Framework Programme', Papers in Regional Science, 88, 531-546.

Scherngell, T. and Y. Hu, (2011) 'Collaborative Knowledge Production in China: Regional Evidence from a Gravity Model Approach', Regional Studies, 45 (6), 755-772.

Talbot, D. (2008), 'Les institutions créatrices de proximité', Revue d'Economie Régionale et Urbaine', 3, 289-310.

Torre, A. (2006), 'Clusters et systèmes locaux d'innovation. Un retour critique sur les hypothèses naturalistes de la transmission des connaissances à l'aide des catégories de l'Économie de la proximité', Régions et Développement, 24, 15-44.

Torre, A. (2008), 'On the role played by temporary geographical proximity in knowledge transmission', Regional Studies, 42 (6), 869-889.

Torre, André and Frédéric Wallet (2014), Regional development and proximity relations, New horizons in regional science, London: Edward Elgar.

Ter Wal, A. (2009), 'The structure and dynamics of knowledge networks: a proximity approach', PhD in Economic Geography presented at Utrecht University, http://dspace.library.uu.nl/handle/1874/36544

Ter Wal, A. and R. Boschma (2009), 'Applying social network analysis in economic geography: framing some key analytic issues', Annals of Regional Science, 43, 739-56.

Ter Wal, A., and R. Boschma (2011), 'Co-evolution of firms, industries and networks in space', Regional Studies, 45, 919-933.

Ter Wal, A. (2013), 'Cluster emergence and network evolution: a longitudinal analysis of the inventor network in Sophia-Antipolis', Regional Studies, 47, 651-668. 
Wanzenböck, I, Scherngell, T, and R. Lata (2015), 'Embeddedness of European Regions in European Union-Funded Research and Development (R\&D) Networks: A Spatial Econometric Perspective', Regional Studies, 0 (0), 1-21.

Watts, D. and S. Strogatz (1998), 'Collective dynamics of 'small-world'networks', Nature, 393, 440-442.

Wellman, Barry and Scott Berkowitz (1988), Social Structures: A Network Approach, Cambridge: University of Cambridge.

Wellman, B. (1996), 'Are personal communities local? A Dumptarian Reconsideration', Social Networks, 18, 347-354. 